\title{
The Use of Edmodo in English Language Teaching for Senior High School in Surabaya Miki Hartono $^{1^{*}}$
}

\author{
${ }^{1}$ SMA Negeri 2 Surabaya, Surabaya, Indonesia \\ *E-mail address: miky.sby@gmail.com
}

\begin{abstract}
Edmodo is one online learning platform which is accessible for teachers, students, and parents. This research aims to investigate the impact of using the Edmodo among the students in Surabaya as well as their attitudes toward the use of Edmodo in English classroom. This was an action research on utilizing Edmodo in English classroom in one public senior high school in Surabaya. In addition, reflection among students was accommodated to determine students' attitudes toward Edmodo in the classroom. The findings of this research show that using Edmodo leads to an improvement in students' English skills. As part of reflection, students show positive attitudes toward the use of Edmodo in their class. Further studies should be conducted to investigate the further impact of Edmodo with diverse themes. In addition, some technical challenges of using Edmodo in the English classroom also need to be investigated in further studies.
\end{abstract}

Keywords: Edmodo, English language teaching, senior high school, attitudes

\section{INTRODUCTION}

The current trend of communication technologies, including social networks has opened new opportunities for the development of education system. Using technology in education is believed to help students as well as the teachers to address learning challenges regarding specific times and locations. For this matter, information technology (IT) has become an integrated component of any education system (Tarun, 2019). As the emerging of online learning management, the presence of media social platforms which focus on education is becoming crucial. One example of social media platform for education is Edmodo. Edmodo network is one of the most popular platform which can be utilized into education process. It is an academic communication platform that allows teachers and tutors to provide their courses online as well as connects the teachers with the students and also their parents (Cheong, 2010).

With the presence of information technology and the trend of online learning management, teachers and students are now able to remain connected without being limited to time and place; this includes the trend of online courses through learning online systems. We cannot deny the roles of information technology in learning; we should embrace with the vast development of technology to be integrated into our learning process. Several online platforms, including social media, are available on the Internet which are easy to access and interact with academic material. As the social media is used regularly intensively, the platforms can be combined with certain features like in the classroom to provide both learners and teachers with exciting applications through which to connect, interact, collaborate, and share content in a safe, enjoyable, and secure manner (Joko \& Septia, 2018).

In the context of Indonesia, the trend of Industrial Revolution 4.0. gains more attention from government and educational practitioners. One of the most common proposal to answer the challenges of Revolution 4.0 is the adoption of e-learning system. In the context of education, Edmodo has been well-known in Indonesian academicians. Some rationales why people are preferred to Edmodo its familiar features like social media and it is free. Second, it 
was created from scratch for academic purposes. Moreover, it comes with several tools that help teachers with their education design, such as the Library, Messages, Progress, Notifications, and To-Do options.

As an application for academic communication, Edmodo works through contentmanagement systems and integrated learning (online learning management (Cheong, 2010; Joko \& Septia, 2018). With the popularity of Edmodo among educators, this platform allows them to have blended learning or flipped classroom, an instructional model that is meant to make the best use of cutting-edge technology such as the Internet. Using this model, teachers are able to address the lessons for the students by integrating several sources like video and audio files, as well as other resources Web 2.0. technology to give direct message and input to the platform.

The integration of technology, particularly the education social media platform like Edmodo, allows students to experience off-class learning process through their personal computer (laptop), Smartphone, or tablet; the students do their activities at home or everywhere. When they come into the classroom, they had had basic knowledge and sufficient schemata for classroom participation and engagement. For this, Edmodo is believed to help community to close the gaps between students with regard to their access to education, thus improving learning outcomes (Terry \& Doolittle, 2006; Mokhtar, 2018). Edmodo makes learning more interesting; it is current, uses easy-to-understand components, and is easily accessible.

This study is intended to elaborate the implementation of Edmodo into the English courses for senior high students. More specifically, this research is focuses on two main discussions, namely on how Edmodo affects students' skills and how students' attitudes toward the use of Edmodo in English classroom.

\section{METHOD}

This is an action research involving senior high school students $(\mathrm{N}=30)$ of one public school in Surabaya (eleventh grade). The school is located in the urban setting, assuming that all students involved had access to information and technology through their technological devices, either their Smartphone or personal computer or laptop. As the researcher is the classroom teacher, it is believed to have full access to give intervention to the classroom by considering the assigned curriculum, adapting Hopkins' spiral action research which included planning, implementing (action), observing, and reflecting (Hopkins \& Ahtaridou, 1993). The action was conducted in one two cycles consisting of 8 meetings (90 minutes for each) or equals to one month of intervention.

There were two instruments employed to obtain the data in this action research, namely observation checklist to elaborate the instructional strategies in the classroom and questionnaire during reflection session in order to know students' attitudes toward the use of Edmodo in the classroom. Data were analyzed through pre-test and post-test were employed before and after the intervention of using Edmodo. As this was integrated English classroom, instead of discrete classroom, the assessment was conducted holistically in terms of students' knowledge and academic achievement.

\section{FINDINGS AND DISCUSSION}

This section focuses on two main aspects of the study, namely how the Edmodo was employed into English classroom and also the impact on students' academic performance. Secondly, the study presents the students' attitudes toward the utilization of Edmodo in their English classroom. 


\section{STUDENTS' ACADEMIC PERFORMANCE BY USING EDMODO IN THE ENGLISH CLASSROOM}

In order to observe students' performance in relation with the use of Edmodo in the classroom, pre-test and post-test were employed. The following is the changes of students' academic performance during the action research.

Table 1. Results of the Test

\begin{tabular}{ccccc}
\hline \multirow{2}{*}{ Students } & \multirow{2}{*}{ Number } & \multicolumn{3}{c}{ Average scores } \\
\cline { 3 - 5 } & & Pre-test & Formative test 1 & Formative test 2 \\
\hline $11^{\text {th }}$ grade & 30 & 65.4 & 71.6 & 85.2 \\
\hline Source: Data processed during pre-test, cycle 1, and cycle 2 &
\end{tabular}

Table 1 illustrates the scores from pre-test and the post-tests (cycle 1 and cycle 2) in the form of formative tests. That indicates the scores show gradual improvement from pre-test to the post-test 1 , while the increase doubled during the cycle 2 from 71.6 to 85.2 (with minimum standard of success is 85.00). In short, Edmodo is believed to have positive impact on students' academic achievement in the English classroom.

Despite the fact that the increase was gradual instead of significant in terms of students' academic performance, however, the classroom observation on students' collaboration and engagement indicated the other way results. The fact is Edmodo increased the use of collaborative e-learning in the classroom, which allowed the students informed.

This result is consistent with some research with the same focus both on senior high school and higher education levels, namely how visual presentation helps students improve their skills in the context of e-learning (Hassan, 2009) and how online learning boosts students' participation and engagement (Roberts, 2005). The rationale why students' engagement through classroom collaboration should be included into one of parameters to observe students' academic performances in online learning is due to some advantages, namely e-learning allows the students to acquire knowledge collaboratively and provides more freedom and flexibility to construct more knowledge and understanding; it is believed to be better than classical and formal learning environments. Additionally, e-learning also encourages exchanges of experience and knowledge among learners. A study reported the significant improvements in students' learning outcomes (aside of language skills) in terms of content in writing class. That happened due to collaborative process of the students in composing their writing in English classroom (Maazi \& Janfeshan, 2018).

In terms of academic performance, it is believed that Edmodo as one of the popular elearning platform has shown positive impact to students' academic performance, particularly in terms of language skills and better engagement and collaboration during learning process.

\section{STUDENTS’ ATTITUDES TOWARD EDMODO IN ENGLISH CLASSROOM}

There are some closed questions presented in a simple questionnaire with Likert's scale 0-5, which 0 constitutes a very low attitude while 5 constitutes a very high attitude. The questions were written in Bahasa Indonesia to avoid misunderstanding or ambiguous questions. Some questions are as follow (English version):

- Do you like using Edmodo?

- Does using Edmodo help you share information?

- Can you collaborate online with your friends? 
- Do you practice more during my course when using Edmodo?

- Do you enjoy a course using Edmodo?

- Is Edmodo a friendly learning environment?

- Is Edmodo an easily-accessible website?

- Can teachers give feedback through Edmodo directly and personally?

- Can you communicate easily with your teachers?

The results obtained through the questionnaire distributed after the learning activities as part of reflection show how students' attitude toward the Edmodo in the English classroom show positive trends. The average score given by the students was 4.02 , with the standard division of 0.731 , indicating that students have a high degree of agreement (positively believe) towards the integration of Edmodo in their class.

As the attitudes show positive trend from the students, this research confirms the easiness and accessible features in Edmodo gave students' comfortable to get involved in the learning process. It is believed that the practicality of this online education platform may improve the students' attitudes even more. The results are consistent with the results of previous studies (Maazi \& Janfeshan, 2018), how Iranian students perceived the presence of Edmodo helps them collaboratively write and improve their writing; thus, who all have found that learners strongly approved of using Edmodo and appreciated the experience of learning with Edmodo.

Another factor that encouraged students to give positive reports for Edmodo is that the instant features such as instant exams and work submission, direct feedback and communication with their teachers, as well as unlimited online modules. In broader context, not only Edmodo, the presence of social media platform like Facebook in the classroom is believed to improve students' perception as well as grow more positive efforts to participate in the online learning process (Piriyasilpa, 2012).

In Indonesian context, the use of Edmodo also increases students' motivation which is in turn believed to increase their performance and attitudes to the media (Nasrullah, Marlina \& Dwiyanti, 2018). Besides, the simplicity of Edmodo in the classroom allows the students feel less stressed when they finished their online assignment or quiz. Another advantage that is closely related to the students' attitude is the current trend that students cannot be separated from technology devices, making them to think of online platform for their learning is more effective.

\section{CONCLUSION}

The results of students' tests illustrate that using the Edmodo leads to statistically improvement in students' academic performance in English classroom. It is believed that the teaching of English by utilizing Edmodo can increase students' engagement and collaboration which in turn will positively affect their learning outcomes. In addition, as the students penned positive trend towards the use of Edmodo in the English classroom, it is believed that it may lead into bigger benefits in learning outcomes as the students gain better motivation and experience practicality of the platform in their learning process, easiness. They believe that the presence of gadget and technology devices allows them to engage in the classroom activities more effectively.

There are some limitations of this study, including limited number of participants and any possible factors that might affect their performance. Other aspects like topic selection should be studied further in order to integrate online learning management more effectively. Lastly, technical issue like internet connection and teacher's control should be analyzed further in order to maintain the smooth of the learning process. 


\section{REFERENCES}

Cheong, D. (2010) The effects of practice teaching sessions in Second Life on the change in pre-service teachers' teaching efficacy. Computers \& Education, 55(2), pp. 868-880.

Hassan, Z. (2009). The impact of interactive multimedia learning methods and e-learning through the Internet in providing the skills of using visual presentations with distance learning. Technology of Education And Education of the Arab Child Conference, 2009.

Hopkins, D. \& Ahtaridou, E. (1993). A Teacher's Guide to Classroom Research. Open University Press.

Joko \& Septia, W.G. (2018). The development of learning management system using Edmodo. IOP Conference Series: Materials Science and Engineering, 336, pp. 12-46.

Maazi, H. \& Janfeshan, K. (2018). The effect of Edmodo social learning network on Iranian EFL learners writing skill. Cogent Education, 5(1), pp. 1-17.

Mokhtar, F.A. (2018) Breaking barriers through Edmodo: A qualitative approach on the perceptions of University of Malaya undergraduates. Online Learning 22(1), pp. 61-80.

Nasrullah, A., Marlina, M., \& Dwiyanti, W. (2018) Development of student worksheet-based college e-learning through Edmodo to maximize the results of learning and motivation in economic mathematics learning. International Journal of Emerging Technologies in Learning (iJET), 13(12), 211-229.

Piriyasilpa, Y. (2012). See you in Facebook: The effects of incorporating online social networking in the language classroom. Journal of Global Management Research, 2(3), pp. 15-27.

Roberts, G.P. (2005). The experience of participants in an online collaborative learning environment. Doctoral Dissertation, University of Tennessee, USA, 2005.

Tarun, I.M.. (2019). The effectiveness of a customized online collaboration tool for teaching and learning. Journal of Information Technology Education: Research, 2019, 18, 275292.

Terry, K. \& Doolittle, P. (2006) Fostering self-regulation in distributed learning. College Quarterly, 2006, 9(1). 